\title{
Erratum to: Human Choice and Computers
}

\author{
Klaus Brunnstein ${ }^{1}$ and Jacques Berleur ${ }^{2}$ \\ 1 Faculty for Informatics, University of Hamburg, Germany \\ 2 Institut d'Informatique, Facultes Universitaire Notre Dame de la Paix, \\ Belgium
}

\section{Erratum to: \\ K. Brunnstein and J. Berleur (Eds.) \\ Human Choice and Computers \\ DOI: $10.1007 / 978-0-387-35609-9$}

The book was inadvertently published with an incorrect name of the copyright holder. The name of the copyright holder for this book is: (c) IFIP International Federation for Information Processing. The book has been updated with the changes.

The updated original online version for this book can be found at DOI: $10.1007 / 978-0-387-35609-9$ 